DOI : $10.14746 /$ rie.2019.13.27

\title{
Agnieszka Nitszke, Janusz Józef Węc (red. naukowa), Podsumo- wanie VIII kadencji PE. Wyzwania integracji europejskiej w la- tach 2014-2019, Wydawnictwo Księgarnia Akademicka, Kraków 2019, ss. 427.
}

U progu rozpoczęcia nowej IX kadencji Parlamentu Europejskiego możemy z pewnej perspektywy powiedzieć, że poprzednia kadencja tej instytucji przebiegała w latach przełomowych dla dalszego procesu integracji na kontynencie. Kryzys migracyjny, którego apogeum miało miejsce w 2015 r., wzrost poparcia dla ugrupowań populistycznych, a niejednokrotnie głoszących skrajne poglądy, czy wreszcie Brexit to najważniejsze wydarzenia, które jak wskazują we Wstępie redaktorzy książki, powinny stać się sygnałem alarmowym dla instytucji i polityków unijnych, że dotychczasowy model i rozwiązania wyczerpały swój potencjał, a państwa członkowskie oczekują zmian. To właśnie te wydarzenia zostaną zapamiętane jako klimat VIII kadencji Parlamentu Europejskiego.

Parlament Europejski jest jedną z trzech ponadnarodowych instytucji w Unii Europejskiej. $\mathrm{Z}$ tego względu wciąż jest on krytykowany za działania sprzeczne $\mathrm{z}$ interesami państw narodowych. Zarzut ten podsycany jest przez dużą skalę zbiurokratyzowania. Parlament Europejski składający się z 751 deputowanych pochodzących z 28 państw członkowskich, który na co dzień posługuje się 24 oficjalnymi językami, jest więc na pewno instytucją skomplikowaną pod względem wewnętrznej organizacji oraz procedur. Zapewne to ten fakt sprawia, że za głosami krytykującymi Parlament Europejski stoi bardziej niezrozumienie niż strach przed realnym zagrożeniem dla suwerenności państw członkowskich.

Tym co skupia dzisiaj uwagę politologów, a co powinno być także coraz częściej uwzględniane w praktyce politycznej, to specyficzna rola i pozycja Parlamentu Europejskiego w systemie politycznym Unii Europejskiej. W procesie rozwoju integracji europejskiej wzrastała ona stopniowo wraz z kolejnymi reformami instytucjonalnymi wprowadzanymi przez zmiany traktatów. Ostatni z nich - traktat lizboński - przyznał Parlamentowi Europejskiemu status prawodawcy równoprawnego z Radą Unii Europejskiej. W praktyce oznacza to, że od prawie dziesięciu lat instytucja ta posiada zwiększony wpływ na określanie polityk sektorowych UE, a co za tym idzie, państwa członkowskie realizując swoje interesy i chcąc wpływać na działalność Unii Europejskiej nie mogą w swoich strategiach pomijać Parlamentu Europejskiego.

Niewiedza rodzi strach i niezrozumienie. Dlatego tak ważne jest systematyczne konfrontowanie przypuszczeń z codzienną praktyką. Parlament Europejski jest jedyną instytucją Unii Europejskiej, która składa się z przedstawicieli obywateli państw członkowskich wybieranych w bezpośrednich wyborach. W założeniu zatem to ona jest im najbliższa $i$ to ona powinna reprezentować ich postulaty. Dlatego społeczeństwo powinno oczekiwać od Parlamentu Europejskiego realizacji takich działań, które bezpośrednio poprawiają bezpieczeństwo i jakość życia. Autorzy publikacji podkreślają, że w powszechnej ocenie VIII kadencji PE najczęściej wymienia się praktyczne dokonania, takie jak zniesienie roamingu, zakaz geoblokowania, dążenie do eliminacji tzw. podwójnych standardów oraz rozszerzenie dostępu do szerokopasmowego Internetu.

W zglobalizowanym świcie postępującej integracji gospodarczej i otwartych granic państwa narodowe samodzielnie nie są w stanie rozwiązać wielu problemów zagrażających ich bezpieczeństwu. Decydenci polityczni, szukając więc odpowiedzi na to, jaki był bilans działania Parlamentu Europejskiego minionej kadencji, powinni zwracać uwagę na ocenę jego skuteczności w walce ze skutkami kryzysu migracyjnego. 
Dla naukowców w podsumowaniu VIII kadencji Parlamentu Europejskiego kluczowe powinno być uchwycenie złożoności i wielowymiarowości działań tej instytucji. Publikacja Podsumowanie VIII kadencji Parlamentu Europejskiego. Wyzwania integracji europejskiej w latach 2014-2019 pod redakcją Agnieszki Nitszke i Janusza Józefa Węca to efekt współpracy badaczy z Uniwersytetu Jagiellońskiego, Uniwersytetu Warszawskiego, Uniwersytetu im. Adama Mickiewicza w Poznaniu, Uniwersytetu Ekonomicznego w Krakowie oraz Uniwersytetu Technologiczno-Humanistycznego im. Kazimierza Pułaskiego w Radomiu. Na szczególną uwagę zasługuje interdyscyplinarny charakter artykułów, wśród których znajdziemy teksty politologiczne, socjologiczne oraz prawnicze. Redaktorzy pozycji do współpracy przy jej tworzeniu zaprosili nie tylko doświadczonych i uznanych badaczy, ale co istotne także praktyków oraz badaczy młodszego pokolenia, doktorantów i studentów. Jak zaznaczyli we wstępie „obraz Parlamentu Europejskiego nie będzie pełny i obiektywny bez spojrzenia nań przez pokolenie, które dorastało już w UE".

Praca składa się z 22 rozdziałów podzielonych tematycznie na 6 części. Na początku znajduje się Wstęp wprowadzający do publikacji, wieńczy ją zaś wykaz najważniejszych skrótów oraz indeks nazwisk.

Część pierwsza, otwierająca pracę zbiorową, traktuje o wpływie Parlamentu Europejskiego VIII kadencji na system polityczny i kwestie ustrojowe Unii Europejskiej. W pierwszym rozdziale Janusz Józef Węc analizuje przebieg reformy mechanizmu wczesnego ostrzegania zaproponowanej przez grupę zadaniową ds. pomocniczości i proporcjonalności działającą w latach 2017-2018. W kolejnym rozdziale Anna Wierzchowska bada, czy zakres kompetencji Parlamentu Europejskiego pozwala mu na kształtowanie zmian ustrojowych i czy wykorzystuje je W sposób efektywny. W trzecim rozdziale Łukasz Danel analizuje zainicjowaną w listopadzie 2015 r. reformę prawa wyborczego, którą zajmował się Parlament VIII kadencji. W artykule kończącym pierwszą część książki Ewa Kamarad zastanawia się, czy mechanizm wzmocnionej współpracy przysłużył się pogłębieniu integracji Europejskiej.

W drugiej części książki autorzy rozdziałów podejmują się analizy interesów narodowych i politycznych w Parlamencie Europejskim VIII kadencji. W pierwszym rozdziale Bogdan Koszel przygląda się aktywności Niemiec w Parlamencie w latach 2014-2019. W drugim rozdziale Beata Kosowska-Gąstoł opisuje, jak przesunięcie sympatii politycznych od euroentuzjastów do eurosceptyków wpłynęło na układ sił poprzedniej kadencji Parlamentu Europejskiego i jaki to może mieć wpływ w latach 2019-2024. W trzecim rozdziale, ostatnim w tej części, Justyna Miecznikowska analizuje pozycję i aktywność austriackich deputowanych do Parlamentu Europejskiego VIII kadencji.

Trzecia część pracy obejmuje rozdziały opisujące jak Parlament Europejski w latach 2014 2019 wywiązywał się z ochrony zasad i wartości Unii Europejskiej. W pierwszym rozdziale Katarzyna Głąbicka-Auleytner opisała postawę Parlamentu VIII kadencji wobec przestrzegania praw człowieka na przykładzie promowania i ochrony praw dziecka. Barbara Curyło w drugim rozdziale skoncentrowała się na zjawisku parlamentaryzacji polityki zewnętrznej Unii Europejskiej oraz na instrumentach, którymi Parlament Europejski starał się wpływać na aktywność międzynarodową Unii. W trzecim rozdziale Bożena Gierat-Bieroń przygląda się aktywności Parlamentu Europejskiego w tworzeniu Programu „Obywatele, Równość, Prawa i Wartości”, w ramach którego w latach 2021-2027 mają być wpierane działania na rzecz wzmocnienia społeczeństwa obywatelskiego Unii Europejskiej.

W czwartej części książki siedmiu autorów przedstawia wnioski z badań nad stanowiskiem Parlamentu Europejskiego VIII kadencji wobec wybranych polityk sektorowych Unii Europejskiej. W pierwszym rozdziale Jan Wiktor Tkaczyński analizuje aktywność Parlamentu w czasie negocjacji Wieloletnich Ram Finansowych na lata 2021-2027. W drugim rozdziale Paulina Antoń przedstawia rolę Parlamentu Europejskiego w kształtowaniu polityki zintegrowanego zarządzania granicami zewnętrznymi Unii. Następnie Wawrzyniec Banach opisuje stanowiska 
frakcji minionej kadencji Parlamentu Europejskiego wobec kryzysu migracyjnego. W czwartym rozdziale Klaudia Kudławiec analizuje postawę Parlamentu wobec reformy strefy euro kontynuowanej na podstawie raportu pięciu przewodniczących z 2015 r. W kolejnym rozdziale Marta Labuda koncentruje się na stanowisku Parlamentu Europejskiego VIII kadencji wobec projektu Partnerstwa Wschodniego ze szczególnym uwzględnieniem Ukrainy. W szóstym rozdziale Monika Sowa bada zachowania Parlamentu wobec takich elementów reformy Wspólnej Polityki Bezpieczeństwa i Obrony jak globalna strategia Unii Europejskiej z 2016 r., stała współpraca strukturalna (PESCO) oraz Europejski Fundusz Obronny. W siódmym - ostatnim rozdziale tej części książki - Olesia Tkachuk analizuje rolę Parlamentu Europejskiego w latach 2014-2029 wobec rozwoju współpracy Unii z państwami sąsiedzkimi.

Piąta część książki zawiera wyniki empirycznych badań ilościowych i jakościowych dotyczących efektywności Parlamentu Europejskiego VIII kadencji. W pierwszym rozdziale Tomasz Kownacki przedstawia wyzwania i dylematy, które napotyka się w badaniach naukowych nad Parlamentem Europejskim. Adama Kirpsza w kolejnym rozdziale prezentuje ilościowe badania, w których stara się odpowiedzieć na pytanie, w jaki sposób wyniki wyborów do Parlamentu Europejskiego z 2019 r. wpłyną na sukces Polski w głosowaniach w Parlamencie IX kadencji. $\mathrm{W}$ trzecim rozdziale, w którym również zaprezentowane zostały wyniki badań ilościowych, Dawid Nowicki weryfikuje czynniki wpływające na reelekcję posłów do Parlamentu Europejskiego.

Ostatnia - szósta - część książki koncentruje się na jednym z najważniejszych problemów Unii Europejskiej, a mianowicie kryzysie migracyjnym i sposobami jego zarządzania w latach 2014-2019. W pierwszym rozdziale Krystian Spodaryk analizuje kwestię szlaków migracyjnych w Afryce w odniesieniu do tematyki bezpieczeństwa regionalnego, koncertując się na przyczynach ich powstawania, aktualnych tendencjach, które je kształtują oraz na perspektywach ich dalszego istnienia. W drugim rozdziale Agnieszka Nitszke przedstawia podstawowe założenia Wspólnego Europejskiego Systemu Azylowego, w jaki sposób zadziałały one w obliczu kryzysu migracyjnego, a także reakcje Unii Europejskiej na pojawiające się niedoskonałości rozwiązań WESA.

MICHAŁ DULAK

Uniwersytet Jagielloński 